\title{
Exotic Ants (Hymenoptera, Formicidae) Invading Mediterranean Europe: a Brief Summary over About 200 Years of Documented Introductions
}

\section{E SCHIFANI}

Section Animal Biology, Department of Biological, Chemical and Pharmaceutical Sciences and Technologies (STEBICEF), University of Palermo, Italy

\section{Article History \\ Edited by \\ Jacques Delabie, UESC, Brazil \\ Received 15 December 2018 \\ Initial acceptance 11 April 2019 \\ Final acceptance 18 April 2019 \\ Publication date 20 August 2019}

\section{Keywords}

Alien species, invasive species, pest species, tramp species, globalization, biodiversity, conservation.

\section{Corresponding author}

Enrico Schifani

University of Palermo

Section Animal Biology

Department of Biological, Chemical

and Pharmaceutical Sciences and

Technologies (STEBICEF)

Via Archirafi 18, I-90123, Palermo, Italy.

E-Mail:enrsc8@gmail.com

\begin{abstract}
Exotic ants have emerged as a relevant topic worldwide because of their remarkable impacts on native ecosystems and human activities. A first regional overview is given on the dozens of exotic ant species recorded in Mediterranean Europe since the end of the $19^{\text {th }}$ century. About 40 exotic ant species, belonging to 17 genera and originating from 5 different biogeographical realms, are currently believed to be established in this region. The genera Nylanderia and Tetramorium are those hosting the larger proportion of species, while the Afrotropical realm is the prevalent source of taxa. According to the available data, France, Greece, Italy and Spain all host a high number of exotic species, which has increased at a dramatic rate during the last decades. On the other hand, Mediterranean countries on the Eastern part of the Adriatic Sea appear to be almost empty of exotic ants, perhaps due to both a lesser number of introductions and a lack of targeted investigations. Neighboring countries of the region do not necessarily have more species in common than those geographically distant. Very little is known on the intra-Mediterranean or intraPalearctic introduction processes which probably occurred prior to the $19^{\text {th }}$ century and on their influence on the current species distribution. The vast majority of the species that are currently established in the region are either restricted to indoor habitats or outdoor anthropogenic habitats, fewer of them were able to colonize semi-natural or natural habitats and very few are recognized as serious pests.
\end{abstract}

\section{Introduction}

Introduction of exotic species is a global problem affecting human activities and whole natural ecosystems. Exotic ants represent only a very tiny fraction of global ant diversity (McGlynn, 1999), and most of them tend not to spread outside the human-modified habitats where they first arrive (Holway et al., 2002). Nonetheless, many others have a significant ecological impact and may become invasive, even outside anthropogenic habitats, sparking serious concern and attention from researchers worldwide (Holway et al., 2002; Lach et al., 2010). Five ant species are considered among one hundred worst alien species in the world, representing almost one third of the terrestrial invertebrates of the list produced by Lowe et al. (2000). Eradication of these species may unfortunately prove to be extremely difficult to achieve if populations are well-established (Holway et al., 2002; Hoffmann et al., 2011; Hoffmann et al., 2016).

In Europe, alien terrestrial invertebrates represent one of the most numerous groups of organisms introduced, and are mostly represented by insects (Roques et al., 2009). An exponential increase of the number of established species is currently being witnessed, and it is expected to continue in relation to globalization and expanding commerce (Roques et al., 2009). Climatic conditions made it so that only very few exotic ant species have become established outside heated buildings in Central and Northern Europe (Seifert, 2018). On the contrary, Mediterranean Europe has seen dozens of 
exotic ant species establishing during the last 200 years in non-heated and even undisturbed natural ecosystems. The Mediterranean basin was recognized as one of the twenty-five biodiversity hotspots worldwide (Myers et al., 2000), and it is host to a rich ant fauna (Borowiec, 2014). Its invasion by the exotic Argentine ant, Linepithema humile (Mayr, 1868), one of the worst invasive aliens in the world according to Lowe et al. (2000), attracted alone dozens of studies, making L. humile the single most-studied ant species of the entire region (e.g. Giraud et al., 2002; Espadaler \& Gómez, 2003; Gómez et al., 2003; Rey \& Espadaler, 2004; Blancafort \& Gómez, 2005; 2006; Carpintero et al., 2005; 2014; Jacquiery et al., 2005; Oliveras et al., 2005a; 2005b; Wetterer \& Wetterer, 2006; Abril et al., 2007; 2010; 2013; Carpintero \& Reyes-López, 2008; Blight et al., 2009; 2010; 2012; Roura Pascual et al., 2009a; 2009b; 2010; Pons et al., 2010; Estany-Tigerström et al., 2010; Abril \& Gómez, 2011; Angulo et al., 2011; Diaz et al., 2014; Centorame et al., 2017; Queiroz \& Alvez, 2018). Displacement of native ants and significant changes in the native ant communities are among the most commonly documented consequences of ant invasions, but in many cases notable effects have been also reported in regard to other invertebrates, vertebrates and plants (Holldöbler \& Wilson, 1990; Holway et al., 2002; Lach et al., 2010).

Currently, records of exotic species in Mediterranean Europe come from a large number of different published studies, including only very few updated syntheses at national level (Salata et al., 2017; Blatrix et al., 2018). No comprehensive look at the exotic ants issue at regional or continental levels has ever been taken, while the same was done in case of organisms whose ecological impacts have been much less documented (e.g. Nentwig, 2015).

\section{Materials and methods}

A 'practical' definition of Mediterranean Europe was given: the sum the European territories of all the countries of the Mediterranean region (see Myers et al., 2000 for the region geographic definition), excluding the microstates (e.g. San Marino), was considered (Fig 1). Following this definition, Albania, Bosnia and Herzegovina, Croatia, France, Greece, Italy, Montenegro, Portugal, Slovenia, Spain and Turkey are the nations whose territories are included at least in part.

These territories are not entirely characterized by a Mediterranean climate, especially in the case of France, whose vast majority is not. However, since the non-Mediterranean areas are usually not witnessing significant exotic ant invasion processes, the European territories of these nations are simplistically considered in their entirety instead of being divided in Mediterranean and non-Mediterranean areas Moreover, in order to facilitate the distinction of exotic from native species, especially in regard to the intra-Mediterranean exotics, all the Mediterranean islands that belong to these countries were excluded with the exceptions of the very large
Corsica, Crete, Sardinia and Sicily. The hundreds of smaller islands of the Mediterranean basin are in fact mostly littleknown from a myrmecological standpoint, and only very few were studied with particular regard to the exotic species (e.g. the Balearic Islands by Gómez \& Espadaler, 2006).

The existing published studies which contain data on exotic ant species in these areas were the main source of data for this study, particularly those which published the first records of certain taxa for a geographic area (Nylander, 1856; Emery, 1869; Korlević, 1886; Mantero, 1908; Forel, 1911; Emery, 1916; Marchal, 1917; Bondroit, 1918; Paoli, 1920; Santschi, 1925; Zimmerman, 1934; Frisque, 1935; Donisthorpe, 1950; Schmitz, 1950; Ceballos, 1956; Bernard, 1968; Espadaler, 1979; Süss, 1979; Acosta \& Martinez, 1983; Agosti \& Collingwood, 1987; Bolton, 1987; Ortiz \& Tinaut, 1987; Kugler, 1988; Poldi et al., 1995; Collingwood \& Prince, 1998; Espadaler, 1999; Bračko, 2000; Espadaler \& Collingwood, 2000; Seifert, 2000; Espadaler \& Espejo, 2002; Seifert, 2003; Reyes \& Espadaler, 2005; Aktaç \& Kiran, 2006; Galkowski, 2008; Jucker et al., 2008; Reyes-López et al., 2008; Ugelviv et al., 2008; Boieiro et al., 2009; CasevitzWeulersse \& Galkowski, 2009; Legakis, 2011; Borowiec \& Salata, 2012; Obregón Romero \& Reyes López, 2012; Sanchez-Garcia \& Espadaler, 2015; Espadaler \& Pradera, 2016; Salata et al., 2017; Blatrix et al., 2018; Espadaler et al., 2018; Schifani \& Alicata, 2018). Exotic ant species that quickly vanish from the areas where they are introduced are unlikely to have any significant impact on native ecosystems. Therefore, only most likely established species were considered in this study. The eventual other published records of the same species after its first discovery in a region, as well as regional and national checklists, were consulted in order to determine if each species was to be considered probably still established or not, and which kind of habitats it had occupied. Whenever no published indication could be found to confirm the surviving of an introduced population, the latter was considered extinct if

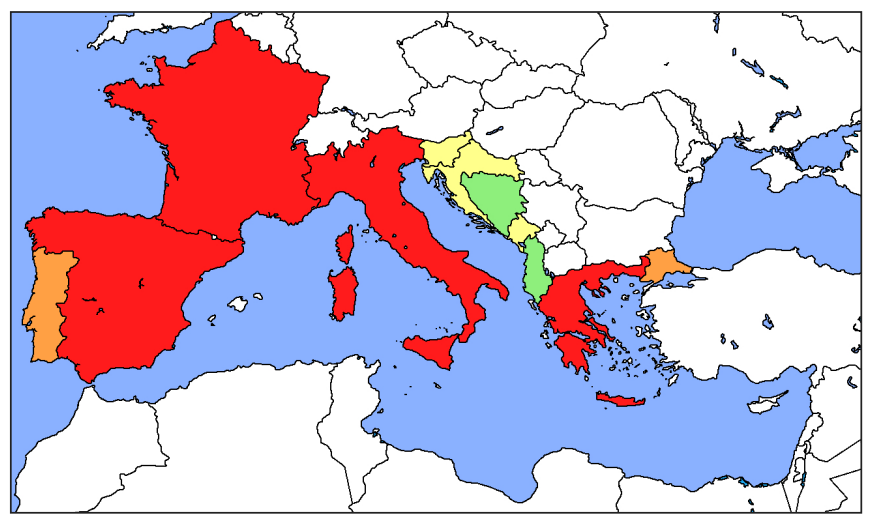

Fig 1. Map of the Mediterranean region. The areas not considered in this study are left blank. Areas hosting no exotic ant species are marked in green, areas hosting a single exotic ant species are marked in yellow, areas hosting 4-7 exotic ant species are marked in orange, the remaining countries, hosting 14-21 exotic ant species, are marked in red. 
more than 15 years had passed without further records after the first, otherwise it was considered established unless published information explicitly suggested differently. Finally, species only recorded at their very first arrival sites (e.g. most of those recorded by Jucker et al., 2008) were not counted, as these introductions are mostly extremely temporary. Antmaps (Janicki et al., 2016) was also often consulted.

\section{Results and Discussion}

A total of 40 different species, belonging to 17 genera and four subfamilies, originating from five biogeographical realms, were found to be currently considered to be present as exotic in Mediterranean Europe and recorded since the second half of the $19^{\text {th }}$ century. The prevalent genera are Nylanderia Emery, 1906 and Tetramorium Mayr, 1855 with 5 species each. The count also includes three provisionally unnamed morphospecies whose identity still needs to be ascertained (Brachymyrmex sp. from France and Nylanderia spp. from Italy - see Blatrix et al., 2018; Schifani \& Alicata, 2018) and a dubious identification (Tetramorium cf. simillimum (Smith, F., 1851) from France - see Blatrix et al., 2018).

Four relatively well-studied countries (France, Greece, Italy and Spain) are characterized by four relatively rich lists of exotic species (Table 1, Fig 1), and similar incremental trends across the decades (Fig 2). Although some of the more recently introduced species may not manage to establish durable populations (thus lowering the '2000' peaks in Fig 2), the vast majority of them are already known as very successful tramp species across other regions of the world (see Antmaps). France is distinguished among the four countries by its comparatively smaller number of exotic species established outdoor (only about $27 \%$ of the list, while $73 \%$ to $90 \%$ in the others), most-likely due to the fact that only a very small part of its territory belongs to the Mediterranean climatic region. In these four countries, the exotic species number represent approximately around $4.5-7.5 \%$ of the entire myrmecofauna present. The Afrotropical realm is always the most important source of species, while the rest of the species origins are mostly divided between the Palearctic, Indomalayan and Neotropical realms (Fig 3). Such pattern is significantly different compared to the one at a global scale (McGlynn, 1999). It is important to note that many of these species are currently widespread across the globe due to human introductions, so that they may have easily been introduced to Europe from areas outside their native range. Five exotic species are actually shared by these four countries (Hypoponera punctatissima (Roger, 1859), Linepithema humile, Monomorium pharaonis (Linnaeus, 1758), Paratrechina longicornis (Latreille, 1802), Tetramorium bicarinatum (Nylander, 1846)), while four others are present in only three of them (Lasius neglectus Van Loon, Boomsma \& Andrasfalvy, 1990, Nylanderia jaegerskioeldi (Mayr, 1904), Pheidole indica Mayr, 1879, Strumigenys membranifera Emery, 1869). In Greece, the presence of $L$. neglectus was initially supposed to be incorrectly recorded due to misidentification with the native $L$. turcicus Santschi, 1921 (Borowiec \& Salata, 2012). Later, the same authors reported to have collected material of both species (Borowiec \& Salata, 2013; Salata \& Borowiec, 2018) and the situation remained unresolved as the two may be conspecific (Borowiec \& Salata, 2017a). In any case, L. neglectus was listed as a nonexotic species in Greece lately (Salata et al., 2017; Salata \& Borowiec, 2018).

The Sørensen-Dice coefficient was used in order to compare the list of these four species-rich countries (Table 2). Very different results were obtained if the comparison was made between all the exotic species of each country, only between those species that managed to establish outdoor or only between those able to colonize non-urban habitats. In any case, the coefficient values that were obtained do not show any strong biogeographic pattern of colonization: neighboring countries do not necessarily show a higher degree of similarity than geographically more distant countries do, suggesting that species often spread through multiple introduction events.

Portugal, whose fauna is usually regarded as relatively much less explored than that of neighboring Spain (Boieiro et al., 2009; Borowiec \& Salata, 2017b) hosts a total of seven exotic species, all shared with Spain with the exception of Strumigenys silvestrii Emery, 1906. The exotic ant fauna of Turkish Thrace (Kiran \& Karaman, 2012), a relatively small region, only counts three species, all shared with neighboring Greece, with the exception of $N$. vividula, which is probably absent from Greece according to Salata et al., 2017. Only $M$. pharaonis, long regarded as the most ubiquitous household ant in the world (Wetterer, 2010), is known in Croatia (Bračko, 2006), Montenegro (Karaman, 2011) and Slovenia (Bračko, 2007).

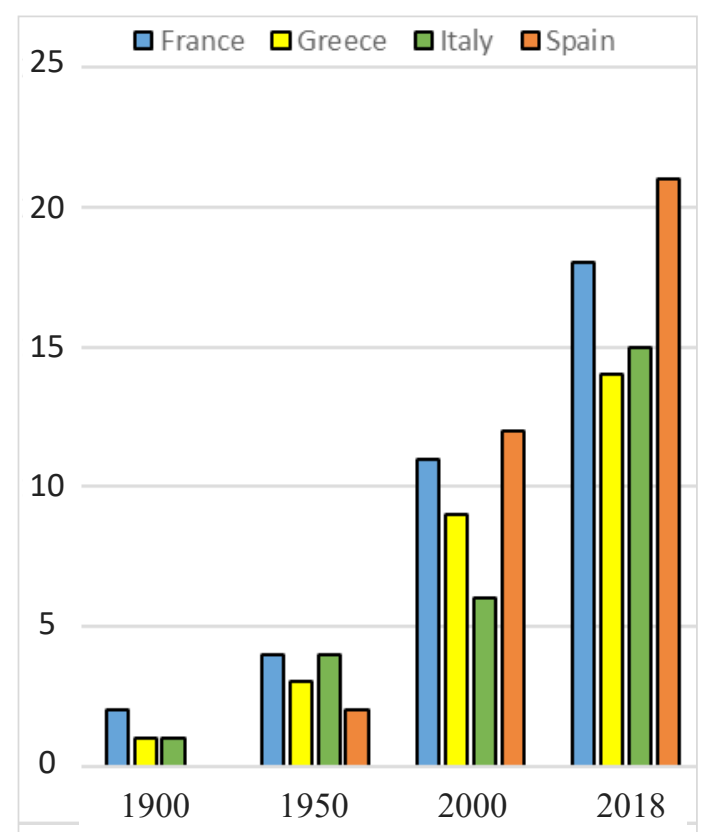

Fig 2. Number of exotic ant species known in France (Corsica, mainland), Greece (Crete, mainland, Peloponnese), Italy (mainland, Sardinia, Sicily) and Spain (mainland) since the beginning of the $1900^{\text {th }}$ century. 
Table 1. Exotic ant species established or seemingly established in France (Corsica, mainland), Greece (Crete, mainland, Peloponnese), Italy (mainland, Sardinia, Sicily) and Spain (mainland). The first confirmed record of the species in each country is presented on the right of the species name. Species that have been found outdoors are marked in yellow, species that have also colonized areas outside urban contexts are marked in red.

\begin{tabular}{|c|c|c|c|c|c|c|c|c|c|}
\hline Species & Croatia & France & Greece & Italy & Montenegro & Portugal & Slovenia & Spain & $\begin{array}{l}\text { Turkish } \\
\text { Thrace }\end{array}$ \\
\hline $\begin{array}{l}\text { Aphaenogaster splendida } \\
\text { (Roger, 1859) }\end{array}$ & & & Roger, 1859 & & & & & & \\
\hline Brachymyrmex sp. & & $\begin{array}{l}\text { Blatrix et al., } \\
2018\end{array}$ & & & & & & & \\
\hline $\begin{array}{l}\text { Brachymyrmex patagonicus } \\
\text { Mayr, } 1868\end{array}$ & & & & & & & & $\begin{array}{l}\text { Espadaler } \\
\text { \& Pradera, } \\
2016\end{array}$ & \\
\hline $\begin{array}{l}\text { Camponotus atriceps } \\
\text { (Smith, F., 1858) }\end{array}$ & & & & $\begin{array}{l}\text { Jucker et al., } \\
2008\end{array}$ & & & & & \\
\hline $\begin{array}{l}\text { Cardiocondyla emeryi } \\
\text { Forel, } 1881\end{array}$ & & & & & & & & $\begin{array}{l}\text { Reyes-López } \\
\text { et al., } 2008\end{array}$ & \\
\hline $\begin{array}{l}\text { Cardiocondyla } \\
\text { mauritanica Forel, } 1890\end{array}$ & & & Seifert, 2003 & & & Seifert, 2003 & & $\begin{array}{c}\text { Ortiz \& } \\
\text { Tinaut, } 1987\end{array}$ & \\
\hline $\begin{array}{l}\text { Cardiocondyla obscurior } \\
\text { Wheeler, W.M., } 1929\end{array}$ & & & & & & & & $\begin{array}{c}\text { Sanchez- } \\
\text { Garcia \& } \\
\text { Espadaler, } \\
2015\end{array}$ & \\
\hline $\begin{array}{l}\text { Hypoponera eduardi } \\
\text { (Forel, 1894) }\end{array}$ & & & $\begin{array}{l}\text { Borowiec \& } \\
\text { Salata, } 2012\end{array}$ & & & & & & $\begin{array}{c}\text { Agosti \& } \\
\text { Collingwood, } \\
1987\end{array}$ \\
\hline $\begin{array}{l}\text { Hypoponera ergatandria } \\
\text { (Forel, 1893) }\end{array}$ & & $\begin{array}{l}\text { Bernard, } \\
1968\end{array}$ & & & & & & & \\
\hline $\begin{array}{l}\text { Hypoponera punctatissima } \\
\text { (Roger, 1859) }\end{array}$ & & $\begin{array}{l}\text { Bernard, } \\
1968\end{array}$ & $\begin{array}{c}\text { Agosti \& } \\
\text { Collingwood, } \\
1987\end{array}$ & Emery, 1916 & & $\begin{array}{c}\text { Collingwood } \\
\text { \& Prince, } \\
1998\end{array}$ & & $\begin{array}{l}\text { Ceballos, } \\
1956\end{array}$ & \\
\hline $\begin{array}{l}\text { Lasius neglectus Van Loon, } \\
\text { Boomsma \& Andrasfalvy, } 1990\end{array}$ & & Seifert, 2000 & & $\begin{array}{l}\text { Poldi et al., } \\
1995\end{array}$ & & & & $\begin{array}{l}\text { Espadaler, } \\
1999\end{array}$ & \\
\hline $\begin{array}{l}\text { Lepisiota syriaca } \\
\text { (André, 1881) }\end{array}$ & & & Stitz, 1928 & & & & & & \\
\hline $\begin{array}{l}\text { Linepithema humile } \\
\text { (Mayr, 1868) }\end{array}$ & & $\begin{array}{l}\text { Marchal, } \\
1917\end{array}$ & $\begin{array}{l}\text { Bernard, } \\
1968\end{array}$ & Paoli, 1920 & & $\begin{array}{l}\text { Schmitz, } \\
1950\end{array}$ & & $\begin{array}{l}\text { Frisque, } \\
1935\end{array}$ & \\
\hline $\begin{array}{l}\text { Monomorium bicolor } \\
\text { Emery, } 1877\end{array}$ & & & $\begin{array}{c}\text { Agosti \& } \\
\text { Collingwood, } \\
1987\end{array}$ & & & & & & \\
\hline $\begin{array}{l}\text { Monomorium carbonarium } \\
\text { (Smith, F., 1858) }\end{array}$ & & $\begin{array}{l}\text { Galkowski, } \\
2008\end{array}$ & & & & $\begin{array}{c}\text { Collingwood } \\
\text { \& Prince, } \\
1998\end{array}$ & & $\begin{array}{c}\text { Espadaler \& } \\
\text { Collingwood, } \\
2000\end{array}$ & \\
\hline $\begin{array}{l}\text { Monomorium monomorium } \\
\text { Bolton, } 1987\end{array}$ & & & Forel, 1911 & & & & & & \\
\hline $\begin{array}{l}\text { Monomorium pharaonis } \\
\text { (Linnaeus, 1758) }\end{array}$ & $\begin{array}{c}\text { Korlevic, } \\
1886\end{array}$ & $\begin{array}{l}\text { Nylander, } \\
1856\end{array}$ & Bolton, 1987 & $\begin{array}{l}\text { Mantero, } \\
1908\end{array}$ & $\begin{array}{l}\text { Zimmermann, } \\
1934\end{array}$ & $\begin{array}{c}\text { Collingwood } \\
\text { \& Prince, } \\
1998\end{array}$ & $\begin{array}{c}\text { Bračko, } \\
2000\end{array}$ & $\begin{array}{l}\text { Santschi, } \\
1925\end{array}$ & $\begin{array}{c}\text { Aktaç \& } \\
\text { Kiran, } 2006\end{array}$ \\
\hline $\begin{array}{l}\text { Nylanderia jaegerskioeldi } \\
\text { (Mayr, 1904) }\end{array}$ & & & $\begin{array}{l}\text { Borowiec \& } \\
\text { Salata, } 2012\end{array}$ & $\begin{array}{c}\text { Schifani \& } \\
\text { Alicata, } 2018\end{array}$ & & $\begin{array}{c}\text { Obregón } \\
\text { Romero \& } \\
\text { Reyes López, } \\
2012\end{array}$ & & $\begin{array}{c}\text { Espadaler \& } \\
\text { Collingwood, } \\
2000\end{array}$ & \\
\hline $\begin{array}{l}\text { Nylanderia vividula } \\
\text { (Nylander, 1846) }\end{array}$ & & $\begin{array}{l}\text { Bernard, } \\
1968\end{array}$ & & & & & & $\begin{array}{c}\text { Espadaler \& } \\
\text { Collingwood, } \\
2000\end{array}$ & $\begin{array}{l}\text { Donisthorpe, } \\
1950\end{array}$ \\
\hline Nylanderia sp. 1 & & & & $\begin{array}{c}\text { Schifani \& } \\
\text { Alicata, } 2018\end{array}$ & & & & & \\
\hline Nylanderia sp. 2 & & & & $\begin{array}{c}\text { Schifani \& } \\
\text { Alicata, } 2018\end{array}$ & & & & & \\
\hline
\end{tabular}


Table 1. Exotic ant species established or seemingly established in France (Corsica, mainland), Greece (Crete, mainland, Peloponnese), Italy (mainland, Sardinia, Sicily) and Spain (mainland). The first confirmed record of the species in each country is presented on the right of the species name. Species that have been found outdoors are marked in yellow, species that have also colonized areas outside urban contexts are marked in red. (Continuation)

\begin{tabular}{|c|c|c|c|c|c|c|c|c|c|}
\hline Species & Croatia & France & Greece & Italy & Montenegro & Portugal & Slovenia & Spain & $\begin{array}{l}\text { Turkish } \\
\text { Thrace }\end{array}$ \\
\hline $\begin{array}{l}\text { Paratrechina longicornis } \\
\text { (Latreille, 1802) }\end{array}$ & & $\begin{array}{l}\text { Nylander, } \\
1856\end{array}$ & Kugler, 1988 & Süss, 1979 & & & & $\begin{array}{l}\text { Espadaler \& } \\
\text { Collingwood, } \\
2000\end{array}$ & \\
\hline $\begin{array}{l}\text { Pheidole anastasii } \\
\text { (Emery, 1896) }\end{array}$ & & $\begin{array}{c}\text { Bernard, } \\
1968\end{array}$ & & & & & & & \\
\hline Pheidole bilimeki Mayr, 1870 & & $\begin{array}{l}\text { Casevitz- } \\
\text { Weulersse \& } \\
\text { Galkowski, } \\
2009\end{array}$ & & & & & & & \\
\hline Pheidole indica Mayr, 1879 & & & $\begin{array}{c}\text { Legakis, } \\
2011\end{array}$ & $\begin{array}{c}\text { Schifani \& } \\
\text { Alicata, } 2018\end{array}$ & & & & $\begin{array}{c}\text { Acosta \& } \\
\text { Martinez, } \\
1983\end{array}$ & \\
\hline $\begin{array}{l}\text { Pheidole megacephala } \\
\text { (Fabricius, 1793) }\end{array}$ & & $\begin{array}{c}\text { Bernard, } \\
1968\end{array}$ & & & & & & $\begin{array}{l}\text { Espadaler } \\
\text { \& Pradera, } \\
2016\end{array}$ & \\
\hline $\begin{array}{l}\text { Plagiolepis alluaudi } \\
\text { Emery, } 1894\end{array}$ & & $\begin{array}{c}\text { Blatrix et al., } \\
2018\end{array}$ & & & & & & & \\
\hline $\begin{array}{l}\text { Strumigenys membranifera } \\
\text { Emery, } 1869\end{array}$ & & & $\begin{array}{c}\text { Agosti \& } \\
\text { Collingwood, } \\
1987\end{array}$ & Emery, 1869 & & & & $\begin{array}{l}\text { Espadaler, } \\
1979\end{array}$ & \\
\hline $\begin{array}{l}\text { Strumigenys silvestrii } \\
\text { Emery, } 1906\end{array}$ & & & & & & $\begin{array}{c}\text { Boieiro et } \\
\text { al., } 2009\end{array}$ & & & \\
\hline $\begin{array}{l}\text { Tapinoma melanocephalum } \\
\text { (Fabricius, 1793) }\end{array}$ & & $\begin{array}{c}\text { Casevitz- } \\
\text { Weulersse \& } \\
\text { Galkowski, } \\
2009\end{array}$ & & & & & & $\begin{array}{c}\text { Espadaler } \\
\text { \& Espejo, } \\
2002\end{array}$ & \\
\hline $\begin{array}{l}\text { Technomyrmex difficilis } \\
\text { Forel, } 1892\end{array}$ & & $\begin{array}{l}\text { Blatrix et al., } \\
2018\end{array}$ & & & & & & & \\
\hline $\begin{array}{l}\text { Technomyrmex pallipes } \\
\text { (Smith, F., 1876) }\end{array}$ & & & & $\begin{array}{l}\text { Jucker et al., } \\
2008\end{array}$ & & & & & \\
\hline $\begin{array}{l}\text { Technomyrmex vitiensis } \\
\text { Mann, } 1921\end{array}$ & & $\begin{array}{l}\text { Blatrix et al., } \\
2018\end{array}$ & & & & & & & \\
\hline $\begin{array}{l}\text { Temnothorax longispinosum } \\
\text { (Roger, 1863) }\end{array}$ & & & & & & & & $\begin{array}{c}\text { Espadaler } \\
\text { \& Colling- } \\
\text { wood, } 2000\end{array}$ & \\
\hline $\begin{array}{l}\text { Tetramorium bicarinatum } \\
\text { (Nylander, 1846) }\end{array}$ & & $\begin{array}{l}\text { Bondroit, } \\
1918\end{array}$ & $\begin{array}{l}\text { Salata et al., } \\
2017\end{array}$ & $\begin{array}{l}\text { Jucker et al., } \\
2008\end{array}$ & & & & $\begin{array}{l}\text { Reyes \& } \\
\text { Espadaler, } \\
2005\end{array}$ & \\
\hline $\begin{array}{l}\text { Tetramorium caldarium } \\
\text { (Roger, 1857) }\end{array}$ & & & & & & & & $\begin{array}{c}\text { Reyes \& } \\
\text { Espadaler, } \\
2005\end{array}$ & \\
\hline $\begin{array}{l}\text { Tetramorium lanuginosum } \\
\text { Mayr, } 1870\end{array}$ & & & & $\begin{array}{c}\text { Schifani \& } \\
\text { Alicata, } 2018\end{array}$ & & & & $\begin{array}{l}\text { Reyes \& } \\
\text { Espadaler, } \\
2005\end{array}$ & \\
\hline $\begin{array}{l}\text { Tetramorium lucayanum } \\
\text { Wheeler, W.M., } 1905\end{array}$ & & & & $\begin{array}{l}\text { Jucker et al., } \\
2008\end{array}$ & & & & & \\
\hline $\begin{array}{l}\text { Tetramorium cf. simillimum } \\
\text { (Smith, F., 1851) }\end{array}$ & & $\begin{array}{c}\text { Bernard, } \\
1968\end{array}$ & & & & & & & \\
\hline $\begin{array}{l}\text { Wasmannia auropunctata } \\
\text { (Roger, 1863) }\end{array}$ & & & & & & & & $\begin{array}{l}\text { Espadaler et } \\
\text { al., } 2018\end{array}$ & \\
\hline
\end{tabular}


No exotic species is currently recorded in Albania and Bosnia and Herzegovina. Such condition of these countries, confirmed in the aforementioned relatively recent checklists, may partly be explained by a lack of targeted searches but may also be partly related to the recent history of the former Yugoslavia, and certainly requires further investigations.

No species were found to be considered exotic in any of the four large islands included in this study while at the same time being considered native in the respective country's mainland or vice-versa.

Some species seem to differ in their invasion success across different countries examined: the same species may be restricted to indoor habitats in a country, be present outdoor but only in anthropogenic habitats in another, and to be present in semi-natural or even natural-habitats in a third one. Such differences can be related to many factors, including environmental aspects and priority effects in the area where the species were introduced, genetic variability and consistence of the introduced population and time-related effects, since many invasion processes are known to be subject to a variety of lag phenomena (Crooks, 2005). While only a small portion of the exotic ants listed in Tab. 1 are considered significantly threatening to semi-natural and natural ecosystems in the Mediterranean basin (Lasius neglectus and Linepithema humile above all), some others have aroused different levels of concern in different countries. For example, Tetramorium bicarinatum, first recorded in the Mediterranean region by Bondroit (1918), is globally considered a low threat (Wetterer, 2009), and usually restricted to indoor areas. However, it has lately started to be reported in outdoor urban contexts in Spain (Reyes \& Espadaler, 2005), Italy (Borowiec \& Salata, 2015; Schifani \& Alicata, 2018) and Greece (Salata et al., 2017). Moreover, in Greece it was also considered by Salata et al. (2017) among the three exotic species that displace native ants in the areas they occupy.

In general, the few species that successfully invaded large areas of outdoor habitats in all the countries considered in this study are mostly distributed in areas characterized by a strictly Mediterranean climate (e.g. Blatrix et al., 2018). A

Table 2. Sørensen-Dice coefficient between exotic ant species present in France - F (Corsica, mainland), Greece - G (Crete, mainland, Peloponnese), Italy - I (mainland, Sicily, Sardinia) and Spain - S (mainland) as defined in this study and listed in Table 1.

\begin{tabular}{cccc}
\hline & All species & $\begin{array}{c}\text { Species established } \\
\text { outdoor }\end{array}$ & $\begin{array}{c}\text { Species established } \\
\text { outside urban habitats }\end{array}$ \\
\hline F-G & $31 \%$ & $11 \%$ & $0 \%$ \\
F-I & $30 \%$ & $37 \%$ & $80 \%$ \\
F-S & $46 \%$ & $33 \%$ & $60 \%$ \\
G-I & $55 \%$ & $54 \%$ & $0 \%$ \\
G-S & $51 \%$ & $46 \%$ & $13 \%$ \\
S-I & $60 \%$ & $60 \%$ & $44 \%$ \\
\hline
\end{tabular}

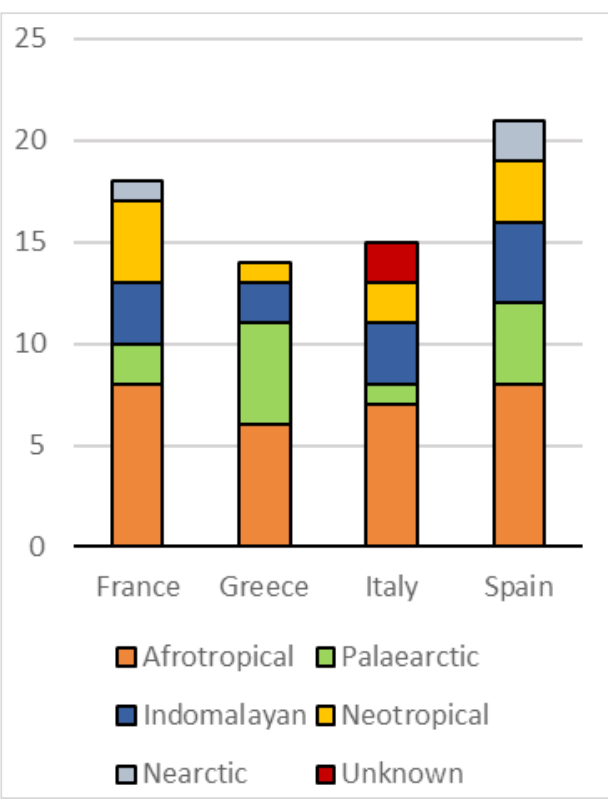

Fig 3. Geographic origin of the exotic ant species of France (Corsica, mainland), Greece (Crete, mainland, Peloponnese), Italy (mainland, Sardinia, Sicily) and Spain (mainland).

significant exception is that of Monomorium carbonarium (Smith, F., 1858), whose presence is mostly distributed along the Atlantic coast of France, while mostly along the Mediterranean in Iberia (Miravete et al., 2013).

Given the long history of human activities and commerce across the Mediterranean basin, many cases of old historical or pre-historical introductions have been detected for both animal and plant species. However, intraMediterranean or intra-Palearctic introductions of ants, usually much less obvious to detect than these of ants from other continents or latitudinal regions, actually represent a mostly unexplored topic. Some cryptic species belonging to the Tapinoma nigerrimum complex and the Tetramorium caespitum complex were only recently recognize as exotic in some or all of the countries in this study after the latest taxonomic advances (Seifert et al., 2017; Wagner et al., 2017). However, the time of their introduction is unknown and thus they were excluded from the present analysis. Another issue is that for a number of other Mediterranean species, there is no precise knowledge about where their native range ends and where the exotic range begins. For example, the status of Cardiocondyla mauritanica Forel, 1890 in Sicily is currently dubious (Schifani \& Alicata, 2018): it is considered as an exotic species in Greece (Salata et al., 2017) and Spain (Reyes \& Espadaler, 2005; Reyes-López et al., 2008), while as likely native to North Africa (Wetterer, 2012). In Sicily, it is found in both natural and anthropogenic habitats, and many species appear to be naturally present in both Sicily and North Africa (Alicata \& Schifani, 2019). Monomorium subopacum (Smith, F., 1858) was considered as exotic in Greece by Salata et al. (2017), while it is usually considered native in the Mediterranean region, however it was removed in a more recent list by the same authors (Salata \& Borowiec, 2018). 
Aphaenogaster splendida (Roger, 1859) may be exotic at least in some parts of the Italian territory (Schifani \& Alicata, 2018) and was only recently treated as an exotic species in Crete (Salata \& Borowiec, 2018). Still, the definition of its native range remains unclear. Similarly, Monomorium monomorium Bolton, 1987 is considered as exotic in Greece (Salata \& Borowiec, 2018) but it is usually considered native in Mediterranean Europe (e.g. Antmaps). Hypoponera eduardi is usually considered native to the Mediterranean, but it is regarded as exotic in Greece (Salata et al., 2017) and Turkey (Kiran \& Karaman, 2012), although Lapeva-Gjonova and Kiran (2012) treat it as a rare species attributing conservation value to an area of Turkish Thrace. Another example can be provided by some forms related to Lepisiota frauenfeldi (Mayr, 1855), whose scattered distributions across the Mediterranean basin may suggest some of these populations are introduced, especially given the vast exotic range attained by $L$. syriaca (André, 1881) in Greece according to Salata et al. (2017) or the recent quick invasion of the Canary Islands by $L$. frauenfeld $i$ cf. kantarensis (Forel, 1911) (Schifani et al., 2018). Molecular data may allow to shed light into this complex and mostly unexplored issue in the future, as in the case of Anochetus ghilianii Forel, 1915 in Southern Spain (Jowers et al., 2015).

\section{Conclusions}

The numerical increase of exotic ant species established in Mediterranean Europe during the last decades is impressive, and so is also the increasing rate at which they continue to be introduced. Nonetheless, other countries around the world are already dealing with much higher numbers of exotic species (e.g. Deyrup et al., 2000). The Balkan countries bordering the Adriatic Sea make an interesting exception in the region, which requires further investigation. It is impossible to predict which species are going to be successful invaders when they arrive, and the ongoing climate change further complicates this equation (Bertelsmeier et al., 2015). Moreover, existing data do not allow to attempt predictions on which species are going to be the next to be introduced in the region, especially that similarity between exotic ants assemblages is not always greater between neighboring countries. While our understanding of invasive ants has tremendously increased over the last decades, long-term effects and dynamics of the invasive populations are little-known since they are just starting to be observed (e.g. Tartally et al., 2016). Our knowledge also remains extremely scarce on those successful ants' introductions that have most likely occurred across the Mediterranean basin in historic and pre-historic times, and on their possible role in shaping the current faunas. The number of species which have caused serious damage and concerns in Mediterranean Europe remains relatively low for the time being. Still, the current situation is concerning for the equilibrium and management of natural and anthropogenic ecosystems in the future.

\section{References}

Abril, S., Oliveras, J. \& Gómez, C. (2007). Foraging activity and dietary spectrum of the Argentine ant (Hymenoptera: Formicidae) in invaded natural areas of the northeast Iberian Peninsula. Environmental Entomology, 36: 1166-1173. doi: 10.1603/0046-225X(2007)36[1166:FAADSO]2.0.CO;2.

Abril, S., Oliveras, J. \& Gómez, C. (2010). Effect of temperature on the development and survival of the Argentine ant, Linepithema humile. Journal of Insect Science, 10: 97. doi: 10.1673/031.010.9701.

Abril, S. \& Gomez, C. (2011). Aggressive behaviour of the two European Argentine ant supercolonies (Hymenoptera: Formicidae) towards displaced native ant species of the northeastern Iberian Peninsula. Myrmecological News, 14: 99-106.

Abril, S., Diaz, M., Enríquez, M. L. \& Gómez, C. (2013). More and bigger queens: a clue to the invasive success of the Argentine ant (Hymenoptera: Formicidae) in natural habitats. Myrmecological News, 18: 19-24.

Acosta, F. J. \& Martínez Ibáñez, M. D. (1983). Pheidole teneriffana Forel, 1983, nueva cita para la Península Ibérica. Boletín de la Asociación Española de Entomología, 7: 320.

Agosti, D. \& Collingwood, C. A. (1987). A provisional list of the Balkan ants (Hym. Formicidae) and a key to the worker caste. I. Synonymic list. Mitteilungen der Schweizerischen Entomologischen Gesellschaft, 60: 51-62.

Aktaç, N. \& Kiran, K. (2006). A new household ant record for Turkish Thrace [Monomorium pharaonis (L.)] (Hymenoptera, Formicidae). Linzer Biologische Beiträge, 38: 1123-1128.

Alicata, A. \& Schifani, E. (2019). Three endemic Aphaenogaster from Siculo-Maltese Archipelago and southern Italian peninsula: part of a hitherto unrecognized species group from Maghreb? (Hymenoptera, Formicidae, Myrmicinae). Acta Entomologica Musei Nationalis Pragae, 59: 1-16. doi: 10.2478/aemnp-2019-0001

Angulo, E., Caut, S. \& Cerdá, X. (2011). Scavenging in Mediterranean ecosystems: effect of the invasive Argentine ant. Biological Invasions, 13: 1183-1194. doi: 10.1007/s10530011-9953-6

Bernard, F. (1968). Faune de l'Europe et du bassin méditerranéen. 3. Les fourmis (Hymenoptera Formicidae) d'Europe occidentale et septentrionale. Masson, $411 \mathrm{p}$

Bertelsmeier, C., Luque, G. M., Hoffmann, B. D. \& Courchamp, F. (2015). Worldwide ant invasions under climate change. Biodiversity and Conservation, 24: 117-128. doi: 10.1007/s10531-014-0794-3.

Blancafort, X. \& Gómez, C. (2005). Consequences of the Argentine ant, Linepithema humile (Mayr), invasion on pollination of Euphorbia characias (L.)(Euphorbiaceae). Acta 
Oecologica, 28: 49-55. doi: 10.1016/j.actao.2005.02.004.

Blancafort, X. \& Gomez, C. (2006). Downfall of pollen carriage by ants after Argentine ant invasion in two Mediterranean Euphorbia species. Vie et Milieu, 56: 1-4.

Blatrix, R., Colin, T., Wegnez, P., Galkowski, C. \& Geniez, P. (2018). Introduced ants (Hymenoptera: Formicidae) of mainland France and Belgium, with a focus on greenhouses. Annales de la Société entomologique de France, 54: 293-308. doi: 10.1080/00379271.2018.1490927.

Blight, O., Orgeas, J., Renucci, M., Tirard, A. \& Provost, E. (2009). Where and how Argentine ant (Linepithema humile) spreads in Corsica?. Comptes rendus biologies, 332: 747-751. doi: 10.1016/j.crvi.2009.04.005.

Blight, O., Provost, E., Renucci, M., Tirard \& A., Orgeas J. (2010). A native ant armed to limit the spread of the Argentine ant. Biological Invasions, 12: 3785-3793. doi: 10.1007/s10530010-9770-3.

Blight, O., Berville, L., Vogel, V., Hefetz, A., Renucci, M., Orgeas, J., Provost, E. \& Keller, L. (2012). Variation in the level of aggression, chemical and genetic distance among three supercolonies of the Argentine ant in Europe. Molecular ecology, 21: 4106-4121. doi: 10.1111/j.1365-294X.2012.05668.x.

Boieiro, M., Espadaler, X., Azedo, A. R., Collingwood, C. A. \& Serrano, A. R. M. (2009). One genus and three new ant species for Portugal (Hymenoptera, Formicidae). Boletín de la Sociedad Entomológica Aragonesa 45: 515-517.

Bolton, B. (1987). A review of the Solenopsis genusgroup and revision of Afrotropical Monomorium Mayr (Hymenoptera: Formicidae). Bulletin of the British Museum (Natural History), Entomology, 54: 263-452.

Bondroit, J. (1918). Les fourmis de France et de Belgique. Annales de la Société entomologique de France, 87: 1-174.

Borowiec, L. \& Salata, S. (2012). Ants of Greece-checklist, comments and new faunistic data (Hymenoptera: Formicidae). Genus, 23: 461-563.

Botowiec, L. \& Salata, S. (2013). Ants of Greece-additions and corrections (Hymenoptera: Formicidae). Genus, 24: 335-401.

Borowiec, L. (2014). Catalogue of ants of Europe, the Mediterranean Basin and adjacent regions (Hymenoptera: Formicidae). Genus, 1: 1-340.

Borowiec, L. \& Salata, S. (2015). Pheidole symbiotica Wasmann, 1909, an enigmatic supposed social parasite, is a nematodeinfested form of Pheidole pallidula (Nylander, 1849) (Hymenoptera: Formicidae: Myrmicinae). Sociobiology, 62: 182-186. doi: 10.13102/sociobiology.v62i2.181-186.

Borowiec, L. \& Salata, S. (2017a). Ants of the Peloponnese, Greece (Hymenoptera: Formicidae). Polish Journal of Entomology, 86: 193-236. doi: 10.1515/pjen-2017-0013.
Borowiec, L. \& Salata, S. (2017b). New records of ants (Hymenoptera: Formicidae) from southern Portugal. Acta Entomologica Silesiana, 25: 1-10.

Bračko, G. (2000). Pregled favne mravelj (Hymenoptera: Formicidae) Slovenije. Acta Biologica Slovenica, 43: 37-54.

Bračko, G. (2006). Review of the ant fauna (Hymenoptera: Formicidae) of Croatia. Acta entomologica slovenica, 14: 131-156.

Bračko, G. (2007). Checklist of the ants of Slovenia (Hymenoptera: Formicidae). Natura Sloveniae 9: 15-24.

Carpintero S., Reyes-López J. \& De Reyna, L. A. (2005). Impact of Argentine ants (Linepithema humile) on an arboreal ant community in Doñana National Park, Spain. Biodiversity \& Conservation, 14: 151-163. doi: 10.1007/s10531-005-3947-6.

Carpintero, S. \& Reyes-López, J. (2008). The role of competitive dominance in the invasive ability of the Argentine ant (Linepithema humile). Biological Invasions, 10: 25-35. doi: 10.1007/s10530-007-9103-3.

Carpintero, S., Retana, J., Cerdá, X., Reyes-López, J. \& Arias de Reyna, L. (2014). Exploitative strategies of the invasive Argentine ant (Linepithema humile) and native ant species in a southern Spanish pine forest. Environmental Entomology, 36: 1100-1111.

Casevitz-Weulersse, J. \& Galkowski, C. (2009). Liste actualisée des fourmis de France (Hymenoptera, Formicidae). Bulletin de la Société entomologique de France, 114: 475-510.

Ceballos, G. (1956). Catálogo de los himenópteros de España. Instituto Español de Entomología, Madrid, 554 pp.

Centorame, M., Lancia, A., Mori, E., D'eustacchio, Dario. \& Fanfani, A. (2017). Could Linepithema humile (Hymenoptera Formicidae) influence ant community composition? A preliminary study in a natural area in Italy. Redia, 100: 89-94. doi: 10.19263/REDIA-100.17.11.

Collingwood, C.A. \& Prince, A. (1998). A Guide to Ants of Continental Portugal. Boletim da Sociedade Portuguesa de Entomologia Suplemento, 5: 8-49.

Crooks, J. A. (2005). Lag times and exotic species: The ecology and management of biological invasions in slowmotion1. Ecoscience, 12: 316-329. doi: 10.2980/i1195-686012-3-316.1.

Deyrup, M., Davis, L. \& Cover, S. (2000). Exotic ants in Florida. Transactions of the American Entomological Society, 126: $293-326$

Diaz, M., Abril, S., Enríquez, M. L., \& Gómez, C. (2014). Assessment of the Argentine ant invasion management by means of manual removal of winter nests in mixed cork oak and pine forests. Biological invasions, 16: 315-327. doi: 10.1007/s10530-013-0520-1. 
Donisthorpe, H. (1950). A first instalment of the ants of Turkey. Annals and Magazine of Natural History, 3: 1057-1067.

Emery, C. (1869). Enumerazione dei formicidi che rinvengonsi nei contorni di Napoli con descrizioni di specie nuove o meno conosciute. Annali dell'Accademia degli Aspiranti Naturalisti Secunda Era, 2: 1-26.

Emery, C. (1916). Formiche d'Italia nuove o critiche. Rendiconti delle Sessioni della Reale Accademia delle Scienze dell'Istituto di Bologna, 20: 53-66

Espadaler, X.. (1979). Citas nuevas o interesantes de hormigas para España. Boletín de la Asociación Española de Entomología, 3: 95-101.

Espadaler, X. (1999). Lasius neglectus Van Loon, Boosma \& Andrásfalvy, 1990 a potential pest ant in Spain. Orsis, 14: 43-46.

Espadaler, X. \& Collingwood, C. A. (2000). Transferred ants in the Iberian Peninsula. Nouvelle Revue d'Entomologie, 17: 257-263.

Espadaler, X. \& Espejo, F. (2002). Tapinoma melanocephalum (Fabricius, 1793), a new exotic ant in Spain (Hymenoptera, Formicidae). Orsis, 17: 101-104.

Espadaler, X. \& Gómez, C. (2003). The Argentine ant, Linepithema humile, in the Iberian Peninsula. Sociobiology, 42: 187-192.

Espadaler X. \& Pradera, C. (2016). Brachymyrmex patagonicus and Pheidole megacephala, two new exotic ants in Spain (Hymenoptera, Formicidae). Iberomyrmex, 8: 4-10.

Espadaler X, Pradera C. \& Santana, J. A. (2018). The first outdoornesting population of Wasmannia auropunctata in continental Europe (Hymenoptera, Formicidae). Iberomyrmex, 10: 1-8.

Estany-Tigerström, D., Bas, J. M. \& Pons, P. (2010). Does Argentine ant invasion affect prey availability for foliagegleaning birds?. Biological Invasions, 12: 827-839. doi: 10.1007/ s10530-009-9504-6.

Forel, A. (1911). Fourmis nouvelles ou intéressantes. Bulletin de la Société Vaudoise des Sciences Naturelles, 47: 331-400.

Frisque, K. (1935). La Fourmi d'Argentine Iridomyrmex humilis Mayr dans les serres en Belgique. Annales de la Société Entomologique de Belgique 75: 148-153.

Galkowski, C. (2008). Quelques fourmis nouvelles ou intéressantes pour la faune de France (Hymenoptera, Formicidae). Bulletin de la Société linnéenne de Bordeaux, 143:423-433.

Giraud, T., Pedersen, J. S. \& Keller, L. (2002). Evolution of supercolonies: the Argentine ants of southern Europe. Proceedings of the National Academy of Sciences, 99: 6075-6079

Gómez, C., Pons, P. \& Bas, J. M. (2003). Effects of the Argentine ant Linepithema humile on seed dispersal and seedling emergence of Rhamnus alaternus. Ecography, 26: 532-538.

Gómez, K. \& Espadaler, X. (2006). Exotic ants (Hymenoptera: Formicidae) in the balearic Islands. Myrmecologische Nachrichten, 8: 225-233.

Hoffmann, B., Davis, P., Gott, K., Jennings, C., Joe, S., Krushelnycky, P., Miller, R., Webb G. \& Widmer, M. (2011). Improving ant eradications: details of more successes, a global synthesis and recommendations. Aliens, 31: 16-23.

Hoffmann, B., Luque, M. L., Bellard, C., Holmes, N. D. \& Donlan, C. J. (2016). Improving invasive ant eradication as a conservation tool: A review. Biological Conservation, 198: 37-49. doi: 10.1016/j.biocon.2016.03.036.

Hölldobler, B. \& Wilson, E. O. (1990). The Ants. Harvard University Press, Cambridge, MA.

Holway, D. A., Lach, L., Suarez, A. V., Tsutsui, N. D. \& Case, T. J. (2002). The causes and consequences of ant invasions. Annual Review of Ecology and Systematics, 33: 181-233. doi: 10.1146/annurev.ecolsys.33.010802.150444.

Janicki, J., Narula, N., Ziegler, M., Guénard, B., Economo, E.P. (2016). Visualizing and interacting with large-volume biodiversity data using client-server web-mapping applications: The design and implementation of antmaps.org. Ecological Informatics, 32: 185-193.

Jaquiery J., Vogel V. \& Keller L. (2005). Multilevel genetic analyses of two European supercolonies of the Argentine ant, Linepithema humile. Molecular Ecology, 14: 589-598. doi: 10.1111/j.1365-294X.2005.02433.x.

Jowers, J. M., Taheri, A. \& Reyes-López, J. (2015). The ant Anochetus ghilianii (Hymenoptera, Formicidae), not a Tertiary relict, but an Iberian introduction from North Africa: Evidence from mtDNA analyses. Systematics and Biodiversity, 13: 545-554. doi: 10.1080/14772000.2015.1061065

Jucker, C., Rigato, F. \& Regalin, R. (2008). Exotic ant records from Italy (Hymenoptera Formicidae). Bollettino di Zoologia agraria e di Bachicoltura, 40: 99-107.

Karaman, M. (2011). A catalogue of the ants (Hymenoptera, Formicidae) of Montenegro. Montenegrin Academy of Sciences and Arts, The Section of Natural Sciences 2, Podgorica.

Kiran, K., \& Karaman, C. (2012). First annotated checklist of the ant fauna of Turkey (Hymenoptera: Formicidae). Zootaxa, 3548: 1-38. doi: 10.5281/zenodo.210984.

Korlević, A. (1886). Forró földövi hangya Magyarországban. Rovartani Lapok, 3: 18-19.

Kugler, J. (1988). The zoogeography of social insects of Israel and Sinai. Monographiae Biologicae, 62: 251-276.

Lach, L., Parr, C. \& Abbott, K. (Eds.) (2010). Ant ecology. Oxford University Press, $410 \mathrm{p}$ 
Lapeva-Gjonova, A. \& Kiran, K. (2012). Ant fauna (Hym., Formicidae) of Strandzha (Istranca) Mountain and adjacent Black Sea coast. North-Western Journal of Zoology, 8: 72-84.

Legakis, A. (2011). Annotated list of the ants (Hymenoptera, Formicidae) of Greece. Hellenic Zoological Archives, 7: 1-55.

Lowe, S., Browne, M., Boudjelas, S. \& De Poorter, M. (2000). 100 of the world's worst invasive alien species: a selection from the global invasive species database (Vol. 12). Auckland: Invasive Species Specialist Group.

Mantero, G. (1908). Res Linguisticae XL. Materiali per un catalogo degli Imenotteri liguri. Parte V. - Supplemento ai Formicidi, Crisidi, Braconidi, Mutillidi e Cinipidi. Annali del Museo Civico di Storia Naturale di Genova, 6: 43-74.

Marchal, P. (1917). La fourmi d'Argentine (Iridomyrmex humilis MAYR). Bulletin de la Societé d' Etude et de Vulgarisation de Zoologie et d'Agriculture de Bordeaux, 16: 23-26.

McGlynn, T. P. (1999). The worldwide transfer of ants: geographical distribution and ecological invasions. Journal of Biogeography, 26: 535-548.

Miravete, V., Roura-Pascual, N. \& Gómez, C. (2013). Presence of Monomorium carbonarium (F. Smith, 1858) (Hymenoptera, Formicidae) in the northeastern Iberian Peninsula. Boletín de la Sociedad Entomológica Aragonesa, 53: 339-340.

Myers, N., Mittermeier, R. A., Mittermeier, C. G., Da Fonseca, G. A. \& Kent, J. (2000). Biodiversity hotspots for conservation priorities. Nature, 403: 853-858. doi: 10.1038/35002501.

Nentwig, W. (2015). Introduction, establishment rate, pathways and impact of spiders alien to Europe. Biological Invasions, 17: 2757-2778. doi: 10.1007/s10530-015-0912-5.

Nylander, W. (1856). Synopsis des formicides de France et d'Algérie. Annales des Sciences Naturelles Zoologie et Biologie Animale, 5: 51-109.

Obregón Romero, R. \& Reyes López, J. (2012). Nuevas aportaciones sobre hormigas exóticas para Portugal continental (Hymenoptera: Formicidae). Boletín de la Asociación Española de Entomología, 36: 279-284.

Oliveras, J., Bas, J. M. \& Gómez, C. (2005). Long-term consequences of the alteration of the seed dispersal process of Euphorbia characias due to the Argentine ant invasion. Ecography, 28:662-672. doi: 10.1111/j.2005.0906-7590.04250.x.

Oliveras, J., Bas, J. M., Casellas, D. \& Gómez, C. (2005). Numerical dominance of the Argentine ant vs native ants and consequences on soil resource searching in Mediterranean corkoak forests (Hymenoptera: Formicidae). Sociobiology, 45: 1-16.

Ortiz, F. J. \& Tinaut, A. (1987). Citas nuevas o interesantes de formícidos (Hym. Formicidae) para Andalucía. Boletín de la Asociación Española de Entomología, 11: 31-34.

Paoli, G. (1920). Brevi cenni sulla Formica dell'Argentina
(Iridomyrmex humilis Mayr). Memorie della Società Lunigianese G. Cappellini per la Storia Naturale della Regione, 2: 14-16.

Poldi B., Mei M., Rigato F. 1995. Hymenoptera Formicidae. In: A. Minelli, S. Ruffo, S. La Posta (eds). Checklist delle Specie della Fauna Italiana, Calderini, Bologna, 1-10.

Pons, P., Bas, J. M. \& Estany-Tigerström, D. (2010). Coping with invasive alien species: the Argentine ant and the insectivorous bird assemblage of Mediterranean oak forests. Biodiversity and Conservation, 19: 1711-1723. doi: 10.1007/ s10531-010-9799-8.

Queiroz, A. I., \& Alves, D. (2018). People, transports and the spread of the Argentine and in Europe, from c. 1850 to the present. CEM Cultura, Espaço \& Memória: CITCEM magazine, 7: 37-61.

Rey, S., \& Espadaler, X. (2004). Area-wide management of the invasive garden ant Lasius neglectus (Hymenoptera: Formicidae) in Northeast Spain. Journal of Agricultural and Urban Entomology, 21: 99-112.

Reyes, J. \& Espadaler, X. (2005). Tres nuevas especies foráneas de hormigas para la Península Ibérica (Hymenoptera: Formicidae). Boletín de la Sociedad Entomológica Aragonesa, 36: 263-265.

Reyes-López, J., Ordonez-Urbano, C. \& Carpintero-Ortega, S. 2008. Relacion actualizada de las hormigas alóctonas de Andalucía (Sur de España). Boletín de la Asociación española de Entomología, 32: 81-94.

Roger, J. (1859). Beiträge zur Kenntniss der Ameisenfauna der Mittelmeerländer. I. Berliner Entomologische Zeitschrift, 3: 225-259.

Roques, A., Rabitsch, W., Rasplus, J. Y., Lopez-Vaamonde, C., Nentwig, W. \& Kenis, M. (2009). Alien terrestrial invertebrates of Europe. In Handbook of alien species in Europe (pp. 6379). Springer, Dordrecht.

Roura-Pascual, N., Brotons, L., Peterson, A. T. \& Thuiller, W. (2009a). Consensual predictions of potential distributional areas for invasive species: a case study of Argentine ants in the Iberian Peninsula. Biological Invasions, 11: 1017-1031. doi: 10.1007/s10530-008-9313-3.

Roura-Pascual, N., Bas, J. M., Thuiller, W., Hui, C., Krug, R. M. \& Brotons, L. (2009b). From introduction to equilibrium: reconstructing the invasive pathways of the Argentine ant in a Mediterranean region. Global Change Biology, 15: 21012115. doi: 10.1111/j.1365-2486.2009.01907.x.

Roura-Pascual, N., Bas, J. M. \& Hui, C. (2010). The spread of the Argentine ant: environmental determinants and impacts on native ant communities. Biological Invasions, 12: 23992412. doi: 10.1007/s10530-009-9650-x.

Salata, S., Georgiadis, C., Borowiec, L. (2017). Invasive ant species (Hymenoptera: Formicidae) of Greece and Cyprus. North-Western Journal of Zoology, e171204. 
Salata, S. \& Borowiec, L. (2018). Taxonomic and faunistic notes on Greek ants (Hymenoptera: Formicidae). Annals of The Upper Silesian Museum in Bytom, Entomology, 27: 1-51.

Sanchez-Garcia, D. \& Espadaler, X. (2015). Cardiocondyla obscurior Wheeler, 1929 (Hymenoptera, Formicidae) in Spain. Iberomyrmex, 7: 7-9.

Santschi, F. (1925). Fourmis d'Espagne et autres espéces paléartiques. EOS (Revista española de entomología) 1: 339-360.

Schifani, E. \& Alicata, A. (2018). Exploring the myrmecofauna of Sicily: thirty-one new ant species recorded, including five new to Italy and many new aliens (Hymenoptera, Formicidae). Polish Journal of Entomology, 87: 323-348. doi: 10.2478/pjen2018-0023.

Schifani, E., Gentile, V., Scupola, A. \& Espadaler, X. (2018). Yet another alien: a second species of Lepisiota spreading across the Canary Islands, Spain (Hymenoptera: Formicidae). Fragmenta Entomologica, 50: 61-64. doi: 10.4081/fe.2018.287.

Schmitz, H. (1950). Formicidae quaedam a cl. A. Stärcke determinatae, quas in Lusitania collegit. Brotéria. Ciências Naturais Série Trimestral, 19: 12-16.

Seifert, B. (2000). Rapid range expansion in Lasius neglectus (Hymenoptera, Formicidae) - an Asian invader swamps Europe. Deutsche Entomologische Zeitschrift 47: 173-179.

Seifert, B. (2003). The ant genus Cardiocondyla (Insecta: Hymenoptera: Formicidae) - a taxonomic revision of the C. elegans, C. bulgarica, C. batesii, C. nuda, C. shuckardi, C. stambuloffi, C. wroughtonii, C. emeryi, and C. minutior species groups. Annalen des Naturhistorischen Museums in Wien. Serie B für Botanik und Zoologie, 104: 203-338.

Seifert, B., D'Eustacchio, D., Kaufmann, B., Centorame, M., Lorite, P. \& Modica, M. (2017). Four species within the supercolonial ants of the Tapinoma nigerrimum complex revealed by integrative taxonomy (Hymenoptera: Formicidae). Myrmecological News, 24: 123-144.

Seifert, B. (2018). The Ants of Central and Northern Europe. Lutra, $408 \mathrm{pp}$.

Stitz, H. (1928). Zoologische Streifzüge in Attika, Morea und besonders auf der Insel Kreta. VIII. Hymenoptera:
Formicidae. Abhandlungen des Naturwissenschaftlichen Vereins zu Bremen, 27: 90-91.

Süss, L. (1979). Formiche infestanti l'industria alimentare: esperienze di difesa antiparassitaria. In Domenichini, G. (Ed.), Atti $2^{\circ}$ Simposio "La difesa antiparassitaria nelle industrie alimentari e la protezione degli alimenti", Piacenza 28-30 settembre 1977. Tip.Le.Co., Piacenza, 359-366.

Tartally, A., Antonova, V., Espadaler, X., Csősz, S. \& Czechowski, W. (2016). Collapse of the invasive garden ant, Lasius neglectus, populations in four European countries. Biological Invasions, 18: 3127-3131. doi: 10.1007/s10530016-1227-x.

Ulgevig, L. V., Drijfhout, F. P., Kronauer, D. J., Boomsma, J. J., Pedersen, J. S. \& Cremer, S. (2008) The introduction history of invasive garden ants in Europe: Integrating genetic, chemical and behavioural approaches. BMC Evolutionary Biology, 6: 11. doi: 10.1186/1741-7007-6-11.

Wagner, H. C., Arthofer, W., Seifert, B., Muster, C., Steiner, F. M. \& Schlick-Steiner, B. C. (2017). Light at the end of the tunnel: Integrative taxonomy delimits cryptic species in the Tetramorium caespitum complex (Hymenoptera: Formicidae). Myrmecological News, 25, 95-129.

Wetterer, J. K. \& Wetterer, A. L. (2006). A disjunct Argentine ant metacolony in Macaronesia and southwestern Europe. Biological Invasions, 8: 1123-1129. doi: 10.1007/s10530005-8641-9.

Wetterer, J. K. (2009). Worldwide Spread of the Penny Ant, Tetramorium bicarinatum (Hymenoptera: Formicidae). Sociobiology, 54: 1-20.

Wetterer, J. K. (2010). Worldwide spread of the pharaoh ant, Monomorium pharaonis (Hymenoptera: Formicidae). Myrmecological News, 13: 115-129.

Wetterer, J. K. (2012). Worldwide spread of the moorish sneaking ant, Cardiocondyla mauritanica (Hymenoptera: Formicidae). Sociobiology, 59: 985-997. doi: 10.13102/ sociobiology.v59i3.561.

Zimmerman, S. (1934). Beitrag zur Kenntnis der Ameisenfauna Suddalmatiens. Abhandlungen der (K. K.) ZoologischBotanischen Gesellschaft in Wien Gegründet, 84: 1-65. 